\title{
Exchange Rate Devaluation and Reshuffling of Global Jobs
}

\author{
Luca Macedoni \\ University of California, Davis, U. S. A. \\ Fabio Sdogati \\ Politecnico di Milano, Milano, Italy
}

\begin{abstract}
Current debates presume that devaluation of one country's currency may transfer the production of imported intermediate goods to the devaluating country. This paper argues that in a global production network involving more than two countries in the production of fragments, this presumption may not hold. With a simple Ricardian model of fragmentation, this paper shows that the production of fragments can be transferred only if countries have close comparative advantage. Using data from the World Input Output Database, our model is found to be empirically supported.
\end{abstract}

JEL Classifications: F10

Key Words: International Fragmentation of Production, Exchange Rate

\footnotetext{
* Corresponding Author: Luca Macedoni; Department of Economics, University of California at Davis, 1 Shields Ave, Davis, CA 95616, U. S. A.; Tel: +01 5306016147, E-mail: 1macedoni@ucdavis.edu.

Co-Author: Fabio Sdogati; Dipartimento di Ingegneria Gestionale, Politecnico di Milano, Via Lambruschini 4b 20156 Milano, Italy; Tel: +390223992701, E-mail: fabio.sdogati@polimi.it. 


\section{Introduction}

In their 1982 article Jones and Sanyal described the relevance of international fragmentation of production in the world economy, but it was difficult to foresee the growing impact of such phenomenon, currently presented by the WTO as a revolution in the international division of labor, a revolution comparable to the shift from agriculture to manufacturing of centuries ago (WTO, 2011).

International fragmentation of production is the splitting of a production process in different tasks or fragments, which are then transferred abroad (Jones and Kierzkowski, 1990). Global production networks then arise, with several countries participating in the production of the same finished goods, thus made in the world (WTO, 2011; Baldwin, 2009). Fragmentation caused the secular shift of workers of high per capita income countries from manufacturing to services (Saeger, 1997), rising concerns on employment and wages of high and low skilled workers (Rowthorn and Ramaswamy, 1997; Feenstra and Hanson, 2001). The 2007 crisis gave new strength to those concerns, with various authors and observers invoking the re-shoring of the fragments previously transferred abroad (Leunig, 2011).

Given this huge transformation of the supply side of the economy, some phenomena of international economics, so far taken for granted, may change. Levying tariffs does not protect domestic firms anymore: on the contrary, it increases the cost of imported intermediate goods damaging home firms' competitiveness (Deardorff, 1979). In addition, fragmentation is likely to cause a distortion in trade statistics that can misguide the interpretation of global imbalances (Lamy, 2011). Fragmentation of production may also be held responsible for increased trade volatility (Escaith and Gonguet, 2009) and the coordination of business cycles across countries (Ng, 2010).

This paper investigates the relations between international fragmentation of production and exchange rates, a topic that received little attention so far, with the notable exception of $\mathrm{Wu}$ (2010) $)^{1}$.

We argue that when a finished good is made in the world, discussing the effect of a currency devaluation on the exports of that good takes on a different relevance than when goods are entirely produced in a single country. The crucial point is what happens to fragments allocation when exchange rate variations occur. Since global production networks are, by definition, global in nature, the problem of allocation of tasks is not a bilateral issue, as the standard literature tends to describe it.

How is task allocation modified? This paper maintains that in a global production network of more than two countries producing a continuum of standardized fragments, a devaluation of

\footnotetext{
${ }^{1}$ While $\mathrm{Wu}(2010)$ considers the effects of exchange rate variations on prices and employment, in this paper we are interested in the allocation of the tasks among countries, thus neglecting the monetary issues altogether.
} 
the currency of the country that is importing fragments relative to the currency of the country that is exporting them will transfer the production of fragments from the latter to the former only if the two countries produce sets of fragments close in the continuum, namely, if the importing country has a closer comparative advantage to that supplier than any other suppliers. Otherwise, the devaluating country may not receive fragments, that are rather transferred in another country, whose specialization is thus changed even if its exchange rate was not modified.

\section{Literature Review}

The idea that exchange rate variations modify the allocation of production processes is not new. In fact, substitution between domestic labor and imported inputs is the crucial assumption in open macroeconomic models with intermediate goods. Summarized by Bird and Rajan (2004), those models maintain that a devaluation of the national currency increases the price of the imported intermediate good denominated in a foreign currency. If the imported intermediate good is a raw material that cannot be domestically produced, then the devaluation may be contractionary, due to the domestic price increase (Findlay and Rodriguez, 1979; Gylfason and Schmid, 1983). Otherwise, if the intermediate good can be produced by domestic labor, then under a certain value of the exchange rate, the production of that intermediate good could be transferred to the home country (Das, 1980; Buffie, 1982; Hanson, 1983). Devaluations would then modify the allocation of production processes.

Various models have been produced to deal with the international splitting of production processes. The oldest approach is developed by Vanek (1963) and following authors (McKinnon, 1966; Guisinger, 1969; Melvin, 1969; Warne, 1973; Chang and Mayer, 1973) that study intermediate goods in the theory of effective protection. In a 2x2x2 Hecksher-Ohlin model, in which each final good requires some quantity of the other one, they show that trade in intermediates extends the production possibility frontier of the economies. Deardorff (2001) and Kohler (2001) build three goods model of fragmentation of production: there are two final goods, one of which could be globally fragmented, requiring one middle product. Following Dornbusch, Fisher and Samuelson (1979), several authors (Dixit and Grossman, 1982;Sanyal, 1983; Sarkar, 1984; Marjit, 1985; Feenstra and Hanson, 2001) modeled fragmentation as the completion of a continuum of activities or semi-finished goods. Semi-finished goods are allocated among countries according to their comparative advantages or relative factor endowments. Recently, Grossman and Rossi-Hansberg (2008) discussed the so-called trade in tasks, that occurs to exploit low wages of emerging economies, but it is constrained by offshoring costs. Jones and Sanyal (1982) and Ethier (2005) treated intermediate goods as a factor of production that could be globally purchased. External economies of scale were included in the study of fragmentation of production by Ethier (1979; 1982), and were recently discussed by 
Grossman and Rossi-Hansberg (2011).

Despite the various ways of fragmentation that account for exchange rate variations those models do not yield different results from those obtained by the macro-models we firstly considered. In fact, a devaluation of the currency of the country that is importing an intermediate good would the rise of foreign currency price of that good, making its production more convenient in the home country.

The reason for these similar results is that reallocation of production depends ultimately on a technological variable: the degree of substitution between imported inputs and domestic labor. Components are substitutable, while raw materials are not. However, if production is internationally fragmented, trade is mostly global and not bilateral (Costinot et. al, 2011).

If the production network consists of more than two countries, a devaluation of the currency of the country that is importing fragments will not necessarily transfer those production processes back home. In fact, in global production networks, countries are no longer independent agents (Nordås, 2006): the more-than-two-country assumption forces us to consider relations that were previously neglected. These relations are formally described through our model that develops of a global production network of three countries.

\section{The Model}

Suppose there are three countries $A, B$ and $C$, each one endowed with labor $L_{j}$ where $j$ identifies the country. Each country can produce a tradeable manufactured good, denoted by $X$, and non-tradeable services, identified by $Y$. The production function of $X$ has the Leontief form: $X=\min \left(x_{i}\right)$, where $x_{i}$ is the amount produced of the $i$-th task, alternatively denoted as fragment. Fragments are standardized elementary activities or intermediate goods ${ }^{2}$ of a production process, as in Grossman and Rossi-Hansberg (2008); external economies of scale (Ethier, 1982; Grossman and Rossi-Hansberg, 2011) are thus ignored. The number of fragments can be approximated by a continuum, indexed by $i$, ranging over the interval $[0,1]$. The final assembly is represented assuming that the last task, $i=1$, requires one unit of all the previous ones.

The $i$-th fragment is produced with $\alpha_{j}^{X}(i)$ unit of labor. Let us assume that fragments can be conveniently ordered by increasing labor content, formally:

$$
d \alpha_{j}^{X}(i) / d i>0
$$

\footnotetext{
${ }^{2}$ Many authors stressed the characteristics of tasks that make them easy to offshore. Autor et al. (2003) distinguish among routine and non-routine tasks with the former easy to offshore or being substituted by a computer; Antràs et al. (2006) presents a model routine an non-routine tasks along a continuum, where heterogeneous agents specialize according to their skills; Leamer and Storper (2001) divides tasks according to what type of information they required, tacit or codifiable. The model presented here assumes that fragmentation does not involves offshoring costs, as if the fragments were routine tasks.
} 
For simplicity the function $\alpha_{j}^{X}(i)$ has the following linear form:

$$
\alpha_{j}^{X}(i)=\alpha_{j} i+b j
$$

If a country produces a certain range of fragments, from $i_{\text {in }}$ to $i_{\text {fin }}$, the number of unit of labor required for all the fragments equals:

$$
\alpha_{j}^{x}\left(i_{\text {in }}, i_{\text {fin }}\right)=\int_{i_{\text {in }}}^{i_{\text {fin }}} \alpha_{j}^{x}(i) d i, \quad i_{\text {in }}<i_{\text {fin }}
$$

Unit labor requirements are then $a_{j}^{X}(0,1)$ for the manufacturing good and $a_{j}^{Y}$ for services.

Technology differs across countries: not only the amount of labor for producing one unit of $X$ differs, but also the slope of the curves does. Country $A$ will employ the least amount of labor for producing one unit of $X$, thus having an absolute advantage, and country $C$ the largest. Unit labor requirements for the entire production of $X$ are ordered as follows:

$$
a_{A}^{X}(0,1)<a_{B}^{X}(0,1)<a_{C}^{X}(0,1)
$$

Technology differs also for each fragment, namely in the slope of the curves:

$$
d \alpha_{A}(i) / d i<d \alpha_{B}(i) / d i<d \alpha_{C}(i) / d i
$$

Since tasks are ordered along the continuum by increasing $\alpha_{j}^{X}(i)$, the amount of labor required for producing each task increases more in low-productivity countries than in the high-productivity ones. This means that country $C$ will have a comparative advantage in the production of the earlier stages of $X, B$ in the medium stages, and $A$ in the final ones. Formally,

$$
d \alpha_{C}(i) / d \alpha_{C}(i+d i)<d \alpha_{B}(i) / d \alpha_{B}(i+d i)<d \alpha_{A}(i) / d \alpha_{A}(i+d i)
$$

The three technology curves are represented in Figure 1. 
Figure 1. Unit labor requirements in $i$-stages $\alpha_{j}^{X}(i)$ for each country

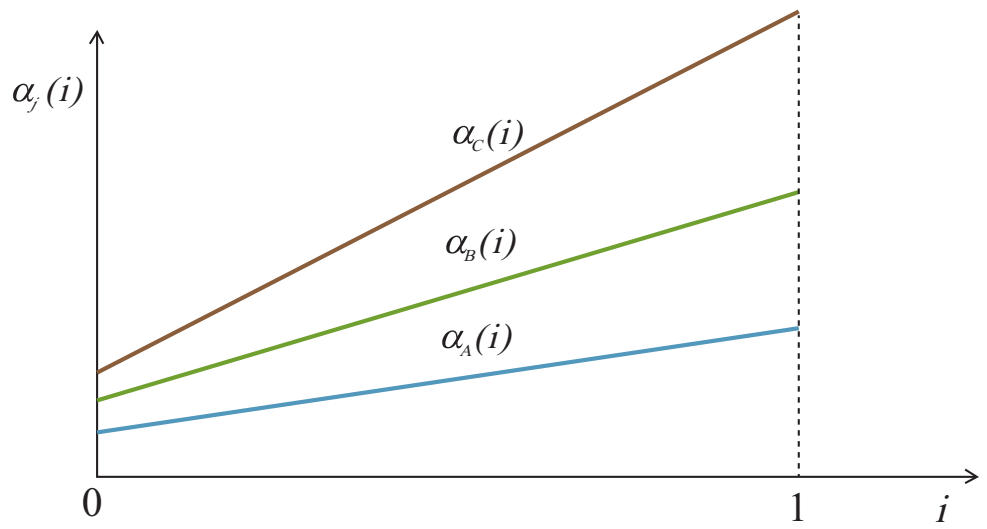

In autarky, equilibrium is assured by the standard full employment condition:

$$
L_{j}=a_{j}^{Y} Y+a_{j}^{X}(0,1) X
$$

Then, in each country wages $w_{j}$ equal:

$$
w_{j}=p_{j}^{Y} / a_{j}^{Y}=p_{j}^{X} / a_{j}^{X}(0,1)
$$

In order to have each country producing fragments of production, wages, assumed fixed, should be ordered in the following way:

$$
w_{A}>w_{B}>w_{C}
$$

As absolute productivities are ordered in the same way, this assumption seems both reasonable and in line with the common hypothesis according to which countries receiving offshored fragments have lower wages (Grossman and Rossi-Hansberg, 2008; Kohler, 2001).

As only the manufacturing good can be traded internationally, free trade has the shape of a global production network that allocates fragments in each country to minimize the cost of production of $X$. Using Baldwin and Venables' (2010) definitions, the global production network is thus shaped as a spider, with country $A$ importing fragments from the other two countries. Defining $p_{j}^{X}(i)$ as the function of the home currency price of each fragment $i$, competitive price condition implies that the price of each fragment equals the product of unit wage and the amount of labor required.

Formally,

$$
p_{j}^{X}(i)=w_{j} \alpha_{j}^{X}(i)
$$


Let us now include the exchange rate $e_{A j}$, defined as the price of one unit of the $j$-th country's currency expressed in units of country $A$ 's currency. Since the final stage of production is located in $A$, the price of all intermediate goods are expressed in $A$ 's currency. Therefore $p_{j}^{X}(i)$ equals:

$$
p_{j}^{X}(i)=e_{A j} w_{j} \alpha_{j}^{X}(i)
$$

Let us assume that $e_{A C}$ and $e_{A B}$ are fixed, while $e_{B C}$ is determined by the first two. For the sake of simplicity, let us assume that there are capital controls preventing financial operators to affect the exchange rate decided by monetary authorities, as in exchange rate regimes of the United States with South-East Asian countries (McKinnon and Schnabl, 2004). In addition to capital controls, let us suppose that the invoice currency of international trade is always the currency of country $A$.

Figure 2. Price functions of the $i$-stages for each country

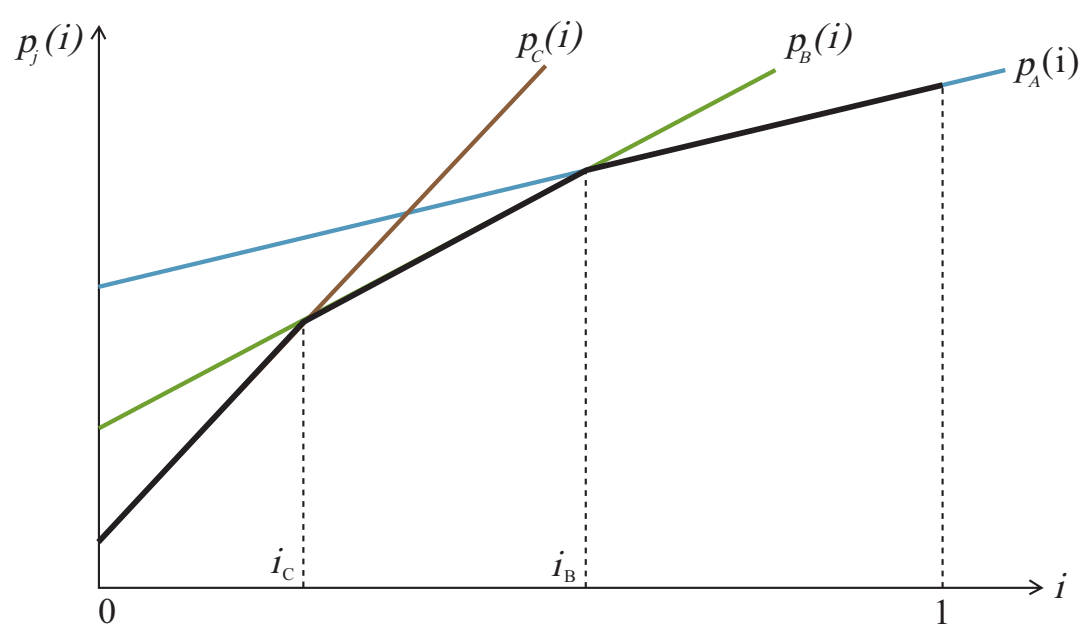

The price functions of the fragments for each country are described in Figure 2. To minimize total cost, each fragment is produced in the country with the least unit cost, namely with the lowest price function. As wages are fixed, they are not modified when production is fragmented. Country $C$ is the most convenient location for fragments in the range $\left[0, i_{C}\right], B$ will specialize in the range $\left[i_{C}, i_{B}\right]$ and $A$ in $\left[i_{B}, 1\right]$. We thus found the international allocation of tasks, namely the ranges of fragments that will be produced in each country, which minimizes the total cost of production.

The price of final good $X$ is the integral of the three segments that identify the lowest cost of each intermediate good. The price of all the intermediates produced in one country is:

$$
p_{j}^{x}\left(i_{i n}, i_{f i n}\right)=e_{A j} \int_{i_{i n}}^{i_{f i n}} w_{j} \alpha_{j}^{x}(i) d i=e_{A j} w_{j} \alpha_{j}^{X}\left(i_{i n}, i_{f i n}\right) i_{f i n} \neq 1
$$


where $i_{\text {in }}$ and $i_{\text {fin }}$ identify the specialization interval of each country. Since only the final task requires all the intermediate activities, $p^{X}(0,1)$ equals

$$
p^{X}(0,1)=e_{A C} w_{C} \alpha_{C}^{X}\left(0, i_{C}\right)+e_{A B} w_{B} \alpha_{B}^{X}\left(i_{C}, i_{B}\right)+w_{A} \alpha_{B}^{X}\left(i_{B}, 1\right)
$$

Given that our interest is in the allocation of production, we assume here that the quantity of $X$ produced is determined by preferences in $A$. Namely, country $A$ decides how much $X$ it desires to consume given its price, and then imports the required fragments. Preferences in $A$ could have the form used by Dornbusch, Fisher and Samuelson (1977), with households consuming a fixed share of their real wage on the non-tradable good and on the tradable one ${ }^{3}$. We may assume that country $B$ and $C$ produce intermediate goods in exchange for finished goods, regardless of their consumption preferences, as in Marjit (1985). The number of units produced in each country for its set of fragments equals:

$$
X\left(i_{1}, i_{2}\right)=\frac{L^{X}}{a\left(i_{1}, i_{2}\right)}
$$

Since preferences in $A$ determine the quantity of $X$ to be produced, equation (14) provides the number of workers employed in the manufacturing industry for each country. Given the Leontief production function, for all the intermediate inputs to be employed in the production of the final good, we need that

$$
X=\frac{L_{A}^{X}}{a_{A}\left(i_{B}, 1\right)}=\frac{L_{B}^{X}}{a_{B}\left(i_{C}, i_{B}\right)}=\frac{L_{C}^{X}}{a_{C}\left(0, i_{C}\right)}
$$

In Figure 3 the functions describing the number of unit of inputs that can be produced are drawn for given values of $L_{j}^{X}$. Hence, given $X$, each country allocates its labor force in the production of $X$ in order to achieve the quantity determined. Since the labor force in each country is employed in two industries, workers are indifferent between working in industry $Y$ or $X$ : labor is therefore allocated to one sector or another in order to achieve condition (15).

${ }^{3}$ This assumption amounts to keeping the number of units of $X$ to be produced fixed. 
Figure 3. Labor force allocation in the $X$ industry

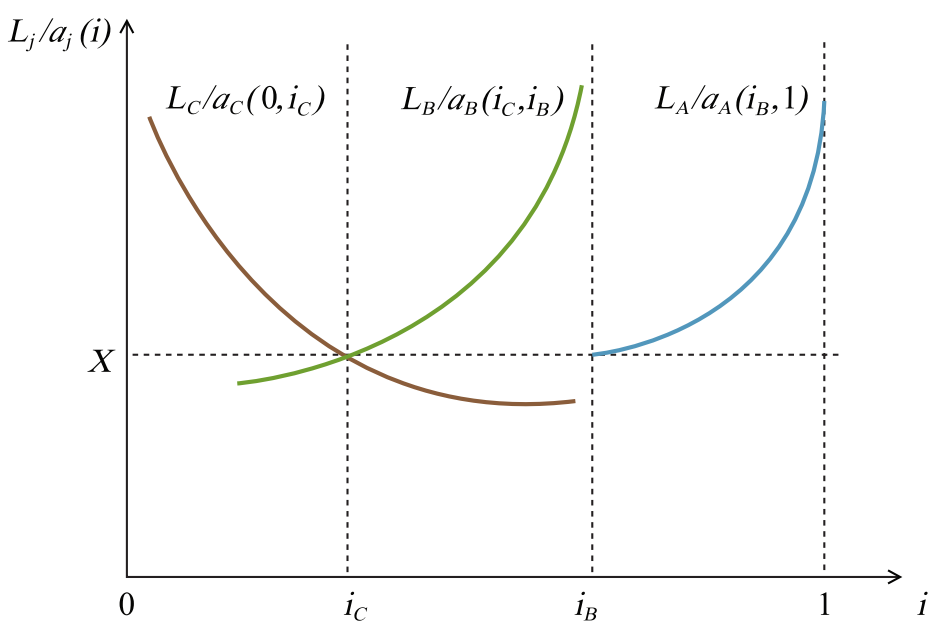

\section{A. Effects of a currency devaluation}

If $A$ 's currency is permanently devalued relative to the currency of country $C$, the foreign currency price of the fragments produced in $C$ will rise. Firms would then find convenient to transfer some fragments from $C$ to $B$, which is the closer country in the continuum. As the range of tasks completed in $B$ is greater, workers in $B$ will leave services to produce the new fragments, while workers in $C$ will leave manufacturing for services. The specialization of $A$ is then unchanged (Figure 4).

Figure 4. Effect of a rise in $e_{A C}$ on the international allocation of activities

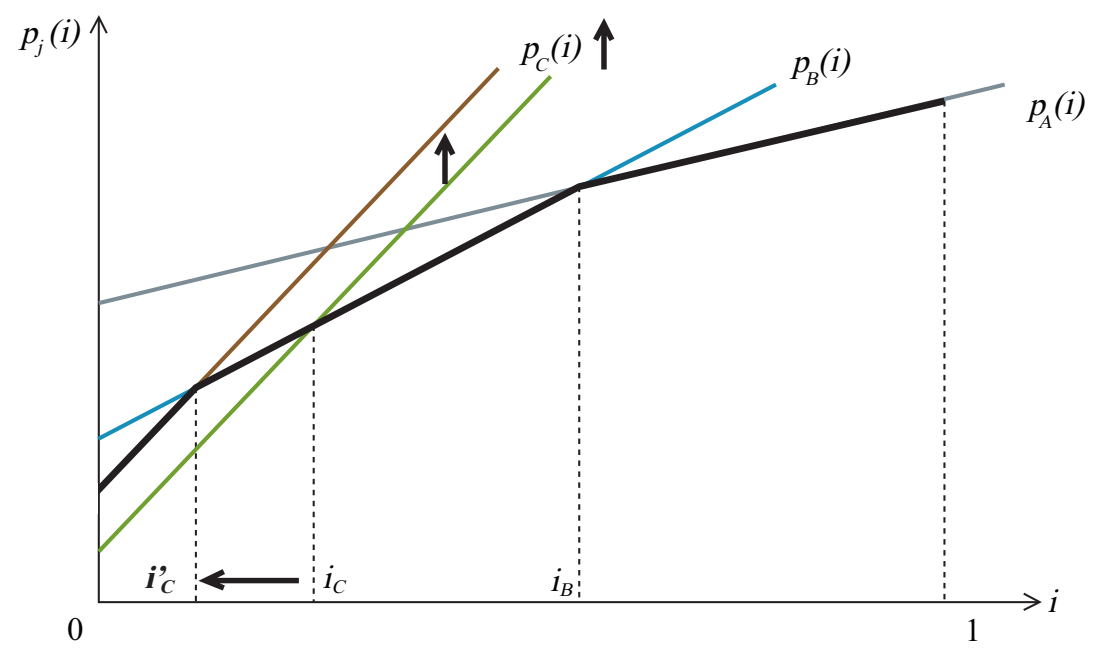


Therefore, devaluating $A$ 's currency vis-à-vis the currency of the country whose range of fragments produced is not adjacent to the one of country $A$, reallocates fragments without having an effect on $A$, except for the price of $X$, which is destined to increase as a result of the more expensive imported fragments. If the share of national income of $A$ spent on $X$ must be constant, the rise in the price of the imported fragments may increase the quantity of $X$ to be produced. It is apparent that an increase of wages in country $C$ will have the same effects: no tasks would be transferred to country $A$, while the specialization of country $B$ would change even if neither its exchange rate nor its wages were modified.

Let us now relax the assumption that a devaluation of $A$ 's currency relative to the currency of $C$ does not affect $e_{A B}$ because of capital controls. In fact, most of the countries in the world are under flexible exchange rate systems, and a bilateral devaluation decided by the authorities is likely to bring about an instantaneous devaluation relative to all the currencies under the flexible regimes ${ }^{4}$. As a result, the price of the fragments produced in $C$ and $B$ will increase (Figure 5). The new specialization points $i_{B}$ and $i_{C}$ are shifted to the left of the $i$-axis, but we cannot infer how much the currency of $B$ will be revaluated relative to the currency of $A$. That shift depends on the extent to which $e_{A B}$ changes after the increase in $e_{A C}$. Hence nothing can be said on the final specialization of $B$ and $C$, namely how much fragments will be transferred from $C$ to $B$ and from $B$ to $A$. Still, the change in the specialization of $A$ is independent from changes in the tasks produced in $C$.

\footnotetext{
${ }^{4}$ In a tri-polar currency system, a bilateral exchange rate variation sets in motion different mechanisms that alter the other bilateral exchange rates too (Melecky, 2008). One of such mechanisms is the non-arbitrage condition, hereafter described taking the dollar, the euro and the yen as an example. Suppose that the exchange rate are such that $1 \$=1 €=1 ¥$, which means that $e_{S \epsilon}=e_{\$ ¥}=e_{\epsilon \neq}=1$. Suppose now that the Federal Reserve decides to devaluate its currency relative to the euro, namely it is willing to exchange $1 \$$ for $0.5 €\left(e_{s \epsilon}\right.$ increases to 2). Given the capital mobility between these three currencies an investor could gain from arbitrage if $e_{S ¥}$ and $e_{\epsilon ¥}$ are kept constant. In fact, an investor that possesses $1 €$ would exchange it for 2 dollars, which would be subsequently traded for $1 ¥$. As the exchange rate of the euro vis-à-vis the yen is not modified, the investor would gain $1 €$ by arbitrage. On the other hand, investors possessing $1 ¥$ would exchange it for $1 €$ and the euro for the dollars, finally obtaining 2 yen. As long as the exchange rate between the dollar and the euro is fixed, these two flows would raise two pressures on the exchange rates: the euro is forced to a revaluation relative to the yen, while demand for the yen would revaluate the Japanese currency relative to the US dollar. The final equilibrium is not certain, being a combination of the two forces in the international financial markets. In fact, the final value of $e_{\$ ¥}$ lies between 0.5 and 1 , while the equilibrium value of $e_{\epsilon \neq}$ lies between 1 and 2 .
} 
Figure 5. The effects of an increase in $e_{A B}$ and $e_{A C}$ on the allocation of tasks : global production network

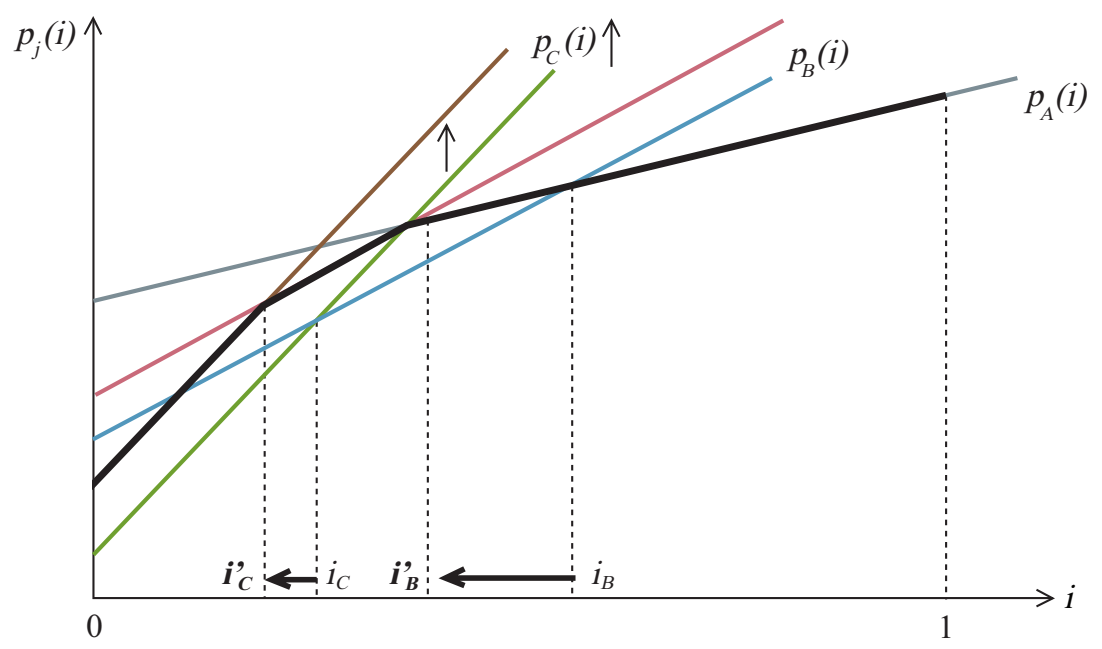

\section{B. Extensions of the model}

The model can be extended to an $N$-country framework, without changing its main results. Suppose that there are $N$ countries indexed by $j=1, \ldots, N$. Assume that countries can be ordered according to their comparative advantages, so that the $N$-th country has a comparative advantage in the production of the latter tasks of the continuum, while country 1 exhibit a comparative advantage in the production of the first tasks of the continuum. This assumption amounts to the following two conditions, which would allow us to draw the production functions of each country as in Figure 1:

$$
\begin{aligned}
& b_{1}>b_{2}>\ldots>b_{j}>\ldots>b_{N} \\
& \alpha_{1}>\alpha_{2}>\ldots>\alpha_{j}>\ldots>\alpha_{N}
\end{aligned}
$$

Under this country ordering, the $i$-th task that identifies the range of specialization for each couple of adjacent countries along the continuum, is the task produced at the same cost in both countries. If we take any $j$-th country, $i_{j, j-1}$ is obtained by:

$$
p_{j}\left(i_{j, j-1}\right)=e_{N j} w_{j} \alpha_{j}^{x}\left(i_{j, j-1}\right)
$$

Defining $\omega_{j}=e_{N j} w_{j}$, the domestic nominal wage expressed in the currency of the $N$-th country (country $A$ of the previous version of the model), we obtain that $i_{j, j-1:}$ 


$$
i_{j, j-1}=\frac{b_{j-1}-\frac{\omega_{j}}{\omega_{j-1}} b_{j}}{\frac{\omega_{j}}{\omega_{j-1}} \alpha_{j}-\alpha_{j-1}}
$$

The task that identifies the range of specialization of two adjacent countries is a decreasing function of the relative wage of the two countries. For the sake of simplicity, as in Costinot et al. (2011), we may assume that that:

$$
0<i_{2,1}<i_{3,2}<\ldots<i_{j, j-1}<\ldots<i_{N, N-1}<1
$$

Using condition (20) we can represent the $i_{j, j-1}$ as a function of the relative wage of two adjacent countries, for each couple of country (Figure 6). Knowing the relative wages of the countries (which are assumed to be fixed), we can identify the specialization of each country of the global production network.

Figure 6. The tasks dividing the specialization of the countries : as a function of the relative wage of two adjacent countries

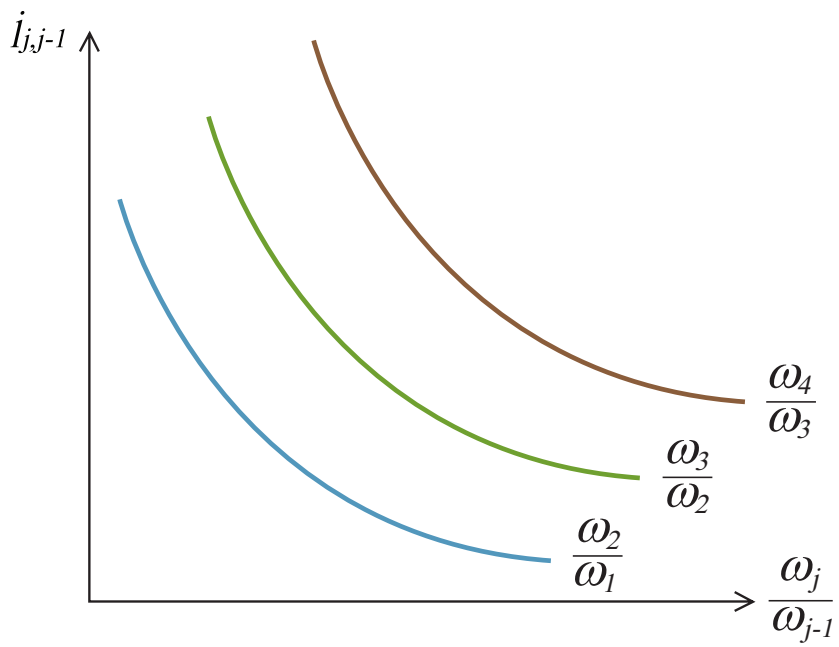

Again, a currency devaluation of the $N$-th country relative to the currency of the $j$-th country will increase $\omega_{j}$, thus reducing the range of activities performed in the $j$-th country. At the same time, country $j-1$ and $j+1$ will see the ranges of fragments produced increase ${ }^{5}$.

\footnotetext{
${ }^{5}$ It is also possible to relax the assumption of fixed wages. If we let condition (15) determine the specialization of each country, in order to reach full employment, then wages would adjust accordingly.
} 


\section{Empirical Analysis}

Given the theoretical model and its results, in this paragraph we will test the following proposition:

In a global production network involving more than two countries that have different comparative advantages and produce a continuum of standardized fragments, a devaluation of the currency of the country that is importing fragments vis-à-vis the currency of one country that is exporting them, will transfer the production of fragments from the latter to the former only if the two countries produce ranges of fragments close in the continuum, namely if the importing country has a closer comparative advantage to the supplier than to any other suppliers.

Empirical literature provides little help to test this proposition, as it has been concerned with other topics. Several contributions test whether wages, economic and geographical distance, and FDIs could explain the international fragmentation of production (Baldone et al., 2001; Fukao et al., 2003; Jones et al., 2005; Gabrish and Segnana, 2008; Turkan and Ates, 2011); another field of empirical work verifies the effects of fragmentation on employment and relative wages of skilled and unskilled workers (Feenstra and Hanson, 1999; 2001; Hijzen et al., 2005; Helg and Tajoli, 2004; Zeddies, 2011), and its effects on economic growth (Baldone et al., 2007; Durking and Krygier, 2000), as well as on trade volatility (Escaith and Gonguet, 2009).

Given that data on intermediate goods trade flows is not directly available, tracking trade in intermediate goods takes different approaches. One of them consists in using Input-Output tables that keep record of the imported intermediate inputs used in production (Hummels et al., 2001; Feenstra et al., 2009; Foster et al.,2011; Johnson and Noguera, 2011). Other methods use indicators to identify whether trade within an industry is vertical or horizontal in nature (Fukao et al., 2003; Ando, 2006; Turkan and Ates, 2011), or employ data on processing imports (Feenstra et al., 1999; Baldone et al., 2001). Finally, it is possible to identify for two digits final industry, i.e., the codes of the internationally traded fragments used in that industry $(\mathrm{Ng}$ and Yeats, 1999; Athukorala, 2005; and Gamberoni et al., 2010).

Here we use data provided by the World Input Output Database, a project funded by the European Commission, which recently produced a set of harmonized supply and use tables of 40 countries. In addition to the value of the imported intermediate goods used in a certain industry, this database provides the country of origin of those intermediate goods, thus fitting the purpose of the following empirical analysis.

\section{A. Studying data}

Given a production network of three countries, in which country $A$ imports fragments em- 
ployed in the production of a certain industry from the other two, the proxy for the allocation of fragments in one country is the ratio between the value of the fragments exported by that country to country $A$ and the value of the intermediate goods employed by the industry considered. To build this proxy, let us recall the price equation (13). The equation can be rewritten in the following way, where the subscript $S$ identifies the final sector of the global production network.

$$
p_{S} X_{S}=e_{A C} p_{C S} X_{C S}+e_{A B} p_{B S} X_{B S}+p_{A S} X_{A S}
$$

Let $\vartheta_{J S}$ be the dependent variable of the empirical model, defined as the share of fragments produced by the $j$-th country in the final production of the $S$-th sector.

$$
\vartheta_{J S}=\left(e_{A J} p_{J S} X_{J S}\right) / p_{S} X_{S}
$$

The proxy for the share of fragments produced in each country is the widely used index of offshoring. This index is computed as the ratio of the imported intermediate goods produced in a certain foreign industry, over the total value of the intermediate goods used in the same industry of the importing country (Feenstra and Hanson, 1996). We will use the index of offshoring deployed for supplying countries: the proxies for the share of fragments produced in each country $J$, belonging to the global production network that produces the product $S$ are the following ratios:

$$
\vartheta_{J S}=I N T_{A, J, S} / \Sigma_{S}\left(I N T_{A, S}\right)
$$

where:

- $I N T_{A, J, S}$ is the cell of the International Input Output(IIO) matrix measuring the value of the intermediate goods imported by country $A$ and used in the $S$ industry, from the same industry of country $J$.

- $\Sigma_{S}\left(I N T_{A, S}\right)$ is the sum of value of all the intermediate goods used in the $S$-th industry of country $A$.

For the country $A$ of the model we used the following expression: $\vartheta_{A S}=1-\Sigma_{J}\left(\vartheta_{A S}\right)$.

The sample used covers 12 industries of the NACE Rev 1.1 classification for 13 highproductivity countries from 1995 to 2009 . We can summarize the characteristics of the two samples in Table 1.

Table 2 presents some preliminary statistics, showing the average share of intermediate goods produced in country $A$ of the model by industry, over the total value of intermediate goods used in the same industry. While some countries domestically produce more than $90 \%$ of the intermediate goods they use (as Italy), others rely more on imported intermediate goods (as Great Britain or Belgium).

Global production networks involve a large share of intra-industry trade among high-productivity countries. However, if we isolate the medium and low-productivity ones, it appears that many industries highly rely on Asian producers, as China, Taiwan and Korea, as well as in 
Easter European countries (Czech Republic, Slovakia, Hungary). Country classifications $A, B$, $C$ in Table 1 is based on the OECD statistics on labor productivity in 2011. The largest exporters of fragments to the countries $A$ considered can be ranked according to their labor productivity. It is possible to identify a group of medium-productivity country (Taiwan, Slovakia, Japan, Czech Republic, Korea, Poland and Turkey) and to isolate a low-productivity one (China).

Table 1. Description of the sample

\begin{tabular}{|l|l|}
\hline Country $A$ & $\begin{array}{l}\text { Austria, Belgium, Canada, Germany, Denmark, Spain, Finland, France, Italy, } \\
\text { Netherlands, Sweden, Great Britain, United States }\end{array}$ \\
\hline Country $B$ & Czech Republic, Hungary, Japan, Korea, Poland, Slovakia, Turkey, Taiwan \\
\hline Country $C$ & China \\
\hline & $\begin{array}{l}17 \text { to } 18 \text { - Manufacture of textiles; Manufacture of wearing apparel; dressing and dyeing of fur } \\
19 \text { - Manufacture of leather and leather products } \\
20 \text { - Manufacture of wood and wood products } \\
21 \text { to } 22 \text { - Manufacture of pulp, paper and paper products; publishing and printing } \\
23 \text { - Manufacture of coke, refined petroleum products and nuclear fuel } \\
24 \text { - Manufacture of chemicals and chemical products } \\
25 \text { - Manufacture of rubber and plastic products } \\
26 \text { - Manufacture of other non-metallic mineral products } \\
27 \text { to } 28 \text { - Manufacture of basic metals and fabricated metal products } \\
29-\text { Manufacture of machinery and equipment n.e.c. } \\
30 \text { to } 33 \text { - Manufacture of electrical and optical equipment } \\
34 \text { to } 35 \text { - Manufacture of transport equipment }\end{array}$ \\
\hline Years & \begin{tabular}{l} 
From 1995 to 2009 \\
\hline
\end{tabular}
\end{tabular}

(Note) Country classification is based on the OECD statistics on labor productivity in 2011.

at http://stats.oecd.org/Index.aspx? Dataset Code=LEVEL 
Table 2. Average share for intermediate goods values produced by high-productivity countries, over the total value of intermediate goods

(1995 2009)

(values as \%)

\begin{tabular}{|c|c|c|c|c|c|c|c|c|c|c|c|c|}
\hline Industry & $\begin{array}{c}17 \text { to } \\
18\end{array}$ & 19 & 20 & $\begin{array}{c}21 \text { to } \\
22\end{array}$ & 23 & 24 & 25 & 26 & $\begin{array}{c}27 \text { to } \\
28\end{array}$ & 29 & $\begin{array}{c}30 \text { to } \\
33\end{array}$ & $\begin{array}{c}34 \text { to } \\
35\end{array}$ \\
\hline Austria & 70 & 79 & 89 & 82 & 99 & 68 & 94 & 93 & 63 & 83 & 69 & 59 \\
\hline Belgium & 69 & 88 & 78 & 70 & 90 & 54 & 92 & 90 & 53 & 78 & 65 & 53 \\
\hline Canada & 77 & 96 & 98 & 92 & 99 & 84 & 96 & 94 & 85 & 96 & 81 & 73 \\
\hline Germany & 75 & 84 & 76 & 77 & 90 & 85 & 97 & 80 & 95 & 95 & 92 & 75 \\
\hline Denmark & 75 & 85 & 75 & 55 & 97 & 75 & 88 & 83 & 56 & 83 & 69 & 96 \\
\hline Spain & 86 & 89 & 92 & 88 & 97 & 80 & 92 & 99 & 85 & 95 & 80 & 75 \\
\hline Finland & 77 & 86 & 98 & 97 & 96 & 77 & 96 & 96 & 75 & 87 & 73 & 83 \\
\hline France & 84 & 88 & 92 & 85 & 97 & 76 & 94 & 99 & 78 & 92 & 79 & 82 \\
\hline Italy & 91 & 94 & 89 & 91 & 99 & 76 & 97 & 98 & 82 & 96 & 87 & 90 \\
\hline Netherlands & 77 & 88 & 76 & 77 & 95 & 65 & 92 & 93 & 64 & 83 & 88 & 72 \\
\hline Sweden & 82 & 89 & 82 & 77 & 98 & 73 & 94 & 98 & 53 & 80 & 70 & 66 \\
\hline Great Britain & 67 & 84 & 74 & 99 & 98 & 67 & 91 & 95 & 67 & 87 & 53 & 68 \\
\hline USA & 97 & 86 & 95 & 97 & 99 & 92 & 99 & 97 & 91 & 96 & 87 & 91 \\
\hline
\end{tabular}

Tables 3 and 5 show, for two selected industries, the average share of intermediate goods produced by the same industry in medium- and low-productivity countries and used in the production of Country $A$ 's industries. On average, European countries imports fragments from medium-productivity countries both from Asia and from Eastern Europe. Chinese textile industry is the largest supplier of intermediate goods employed by the textile industries of highproductivity countries. In the production of electrical and optical equipment, China and Japan are the largest suppliers. The low value of the average share of intermediates produced by those countries is mainly due to the first years of the period considered. In fact, in 2009 the Chinese textile industry account for $16 \%$ of the Canadian demand for intermediate goods in this industry and for $9 \%$ and $6 \%$ of the intermediate goods used in Netherlands and Great Britain. In the production of electrical and optical equipment, in 2009, Germany imported $9 \%$ of its intermediate goods from China, 2\% from Czech Republic and 1\% from Japan. 
Table 3. Average share for intermediate goods value produced by selected low- and medium-productivity countries (rows) used in the production of high-productivity countries (columns), over the total value of intermediate goods

(1995 2009, in manufacturing of textile and wearing apparel, 17 to 18)

(values as \%)

\begin{tabular}{|c|c|c|c|c|c|c|c|c|c|c|c|c|c|}
\hline$A_{A}$ & Austria & $\begin{array}{l}\text { Bel- } \\
\text { gium }\end{array}$ & Canada & $\begin{array}{l}\text { Den- } \\
\text { mark }\end{array}$ & Finland & France & $\begin{array}{l}\text { Ger- } \\
\text { many }\end{array}$ & Italy & $\begin{array}{l}\text { Nether- } \\
\text { lands }\end{array}$ & Spain & $\begin{array}{c}\text { Swe- } \\
\text { den }\end{array}$ & $\begin{array}{r}\text { Great } \\
\text { Britain }\end{array}$ & $\begin{array}{l}\text { United } \\
\text { States }\end{array}$ \\
\hline$\underset{B, C}{\operatorname{County}}{ }^{Q / / b_{y}}$ & 70 & 69 & 77 & 75 & 75 & 86 & 77 & 84 & 91 & 77 & 82 & 67 & 97 \\
\hline China & 3.8 & 3.8 & 6.8 & 3.5 & 1.4 & 1.4 & 3.8 & 1.6 & 3.6 & 1.5 & 1.6 & 3.3 & 0.9 \\
\hline $\begin{array}{c}\text { Czech } \\
\text { Republic }\end{array}$ & 0.9 & 0.2 & 0.1 & 0.2 & 0.3 & 0.1 & 0.9 & 0.3 & 0.2 & 0.1 & 0.2 & 0.2 & 0.0 \\
\hline Hungary & 0.2 & 0.0 & 0.0 & 0.0 & 0.1 & 0.0 & 0.2 & 0.1 & 0.1 & 0.0 & 0.0 & 0.1 & 0.0 \\
\hline Japan & 0.3 & 0.1 & 0.3 & 0.1 & 0.2 & 0.2 & 0.3 & 0.1 & 0.1 & 0.2 & 0.1 & 0.4 & 0.1 \\
\hline Korea & 0.3 & 0.2 & 0.9 & 0.2 & 0.3 & 0.3 & 0.3 & 0.1 & 0.3 & 0.5 & 0.1 & 0.7 & 0.2 \\
\hline Poland & 1.4 & 0.6 & 0.1 & 2.09 & 0.3 & 0.3 & 1.4 & 0.2 & 1.0 & 0.1 & 0.7 & 0.4 & 0.0 \\
\hline Slovakia & 0.2 & 0.0 & 0.0 & 0.0 & 0.0 & 0.0 & 0.2 & 0.0 & 0.0 & 0.0 & 0.0 & 0.1 & 0.0 \\
\hline Turkey & 2.5 & 1.4 & 0.4 & 3.46 & 0.6 & 0.6 & 2.5 & 0.7 & 1.9 & 0.5 & 0.5 & 1.8 & 0.1 \\
\hline Taiwan & 0.2 & 0.2 & 0.6 & 0.2 & 0.1 & 0.2 & 0.2 & 0.1 & 0.2 & 0.1 & 0.2 & 0.4 & 0.1 \\
\hline
\end{tabular}

Table 5. Average share for intermediate goods value produced by selected low- and medium-productivity countries (rows) used in the production of high-productivity countries (columns), over the total value of intermediate goods

(1995 2009, in manufacturing of electrical and optical equipment, 30 to 33)

(values as \%)

\begin{tabular}{|c|c|c|c|c|c|c|c|c|c|c|c|c|c|}
\hline SOAnty & Austria & $\begin{array}{l}\text { Bel- } \\
\text { gium }\end{array}$ & Canada & $\begin{array}{l}\text { Den- } \\
\text { mark }\end{array}$ & Finland & France & $\begin{array}{l}\text { Ger- } \\
\text { many }\end{array}$ & Italy & \begin{tabular}{|c}
$\begin{array}{c}\text { Nether- } \\
\text { lands }\end{array}$ \\
\end{tabular} & Spain & $\begin{array}{c}\text { Swe- } \\
\text { den }\end{array}$ & \begin{tabular}{|l} 
Great \\
Britain
\end{tabular} & $\begin{array}{l}\text { United } \\
\text { States }\end{array}$ \\
\hline 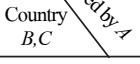 & 69 & 65 & 81 & 92 & 69 & 80 & 73 & 79 & 87 & 88 & 70 & 53 & 87 \\
\hline China & 0.2 & 2.1 & 2.3 & 1.0 & 4.0 & 1.8 & 2.8 & 0.7 & 1.2 & 1.5 & 1.3 & 3.8 & 2.4 \\
\hline $\begin{array}{c}\text { Czech } \\
\text { Republic }\end{array}$ & 0.6 & 0.2 & 0.0 & 0.2 & 0.3 & 0.2 & 1.0 & 0.1 & 0.1 & 0.2 & 0.2 & 0.6 & 0.0 \\
\hline Hungary & 0.2 & 0.4 & 0.0 & 0.2 & 0.7 & 0.4 & 0.9 & 0.2 & 0.1 & 0.4 & 0.6 & 0.7 & 0.0 \\
\hline Japan & 0.4 & 1.6 & 1.1 & 0.4 & 2.3 & 1.1 & 1.6 & 0.2 & 0.6 & 0.6 & 0.7 & 2.2 & 1.3 \\
\hline Korea & 0.1 & 0.3 & 0.7 & 0.2 & 1.0 & 0.5 & 0.9 & 0.2 & 0.1 & 0.4 & 0.4 & 1.3 & 1.0 \\
\hline Poland & 0.4 & 0.5 & 0.0 & 0.4 & 0.3 & 0.3 & 0.5 & 0.2 & 0.2 & 0.3 & 1.1 & 0.6 & 0.0 \\
\hline Slovakia & 0.2 & 0.1 & 0.0 & 0.1 & 0.2 & 0.1 & 0.3 & 0.0 & 0.0 & 0.2 & 0.2 & 0.3 & 0.0 \\
\hline Turkey & 0.1 & 0.2 & 0.0 & 0.2 & 0.1 & 0.1 & 0.2 & 0.1 & 0.0 & 0.2 & 0.1 & 0.5 & 0.0 \\
\hline Taiwan & 0.0 & 0.3 & 0.6 & 0.3 & 0.7 & 0.5 & 0.7 & 0.2 & 0.3 & 0.3 & 0.3 & 0.9 & 1.1 \\
\hline
\end{tabular}


Tables 4 and 6 show, for selected industry the percentage variation of the share of intermediate goods produced by the same industry in medium and low-productivity countries and used in the production of Country $A$ 's industries, over the period from 1995 to 2009. This preliminary evidence shows how the global production networks of those industries evolved in the last fifteen years. It appears to not reject the model's hypothesis. Despite the large increase in the share of fragments produced in the low-productivity country, China, the share of fragments produced in the high-productivity country rarely decreased. The share of fragments usually decreased in the medium-productivity countries, as Japan.

Take the global production network consisting of intermediate goods imported by Italy in the textile industry. The share of fragments produced in Italy increased from 1995 to 2009 by $2 \%$, despite the rise of share of intermediate goods produced in China $(+338 \%)$ and Slovakia $(+544 \%)$. On the other hand, some medium-productivity countries experienced a reduction in the share of fragments produced, like Japan (-60\%), Korea (-57\%) and Taiwan (-10\%).

If we consider the manufacturing of electrical and optical equipment, the evolution of the global production networks seems to be well explained by the model here presented. In fact, the rise of China and other Eastern European countries as suppliers of electrical components has not always reduced the share of fragments produced in the high-productivity countries. In fact, the emergence of low-productivity countries in this production networks have decreased the share of fragments produced in medium-productivity countries; i.e, Taiwan, Korea and Japan.

Table 4. Percentage variation for the share of intermediate goods value produced by selected low- and medium-productivity countries (rows) used in the production of high-productivity countries (columns), over the total value of intermediate goods

(1995 2009, in manufacturing of textile and wearing apparel, 17 to 18)

(values as \%)

\begin{tabular}{|c|c|c|c|c|c|c|c|c|c|c|c|c|c|}
\hline${ }^{A}$ & Austria & $\begin{array}{l}\text { Bel- } \\
\text { gium }\end{array}$ & Canada & $\begin{array}{l}\text { Den- } \\
\text { mark }\end{array}$ & Finland & France & $\begin{array}{l}\text { Ger- } \\
\text { many }\end{array}$ & Italy & $\begin{array}{c}\text { Nether- } \\
\text { lands }\end{array}$ & Spain & $\begin{array}{c}\text { Swe- } \\
\text { den }\end{array}$ & $\begin{array}{c}\text { Great } \\
\text { Britain }\end{array}$ & $\begin{array}{l}\text { United } \\
\text { States }\end{array}$ \\
\hline untry $B_{B, C}$ & 0 & -1 & -4 & 2 & 12 & 10 & -1 & 2 & 5 & 0 & 4 & 19 & -2 \\
\hline China & 510 & 1693 & 610 & 179 & 374 & 434 & 1100 & 338 & 751 & 905 & 825 & 285 & 656 \\
\hline $\begin{array}{c}\text { Czech } \\
\text { Republic }\end{array}$ & 75 & 67 & -79 & -41 & -19 & 83 & -22 & 84 & -29 & 44 & -80 & 59 & 36 \\
\hline Hungary & -26 & 13 & 24 & -77 & -63 & 269 & 157 & 58 & -61 & 849 & -85 & 94 & 507 \\
\hline Japan & 15 & -34 & -87 & -67 & -61 & -71 & -90 & -60 & -78 & -85 & -92 & -84 & -45 \\
\hline Korea & -28 & -54 & -89 & -94 & -49 & -63 & -81 & -57 & -81 & -84 & -70 & -70 & -46 \\
\hline Poland & 773 & 10 & -47 & -2 & 2 & 633 & 268 & 373 & 657 & 2133 & 2 & 22 & 1 \\
\hline Slovakia & 9 & 12 & 45 & 59 & 44 & 89 & 34 & 544 & -18 & 32217 & 13 & 249 & 204 \\
\hline Turkey & 101 & 132 & -53 & 0 & 415 & -47 & 289 & 9 & 0 & 226 & 229 & -33 & 14 \\
\hline Taiwan & 51 & -68 & -71 & -82 & 15 & -81 & -58 & -10 & -64 & -39 & -86 & -63 & -33 \\
\hline
\end{tabular}


Table 6. Percentage variation for the share of intermediate goods values produced by low- and medium-productivity countries (rows) used in the production of high-productivity countries (columns), over the total value of intermediate goods

(1995 2009, in manufacturing of electrical and optical equipment, 30 to 33)

(values as \%)

\begin{tabular}{|c|c|c|c|c|c|c|c|c|c|c|c|c|c|}
\hline$A^{A}$ & Austria & $\begin{array}{l}\text { Bel- } \\
\text { gium }\end{array}$ & Canada & \begin{tabular}{|l|} 
Den- \\
mark
\end{tabular} & Finland & France & $\begin{array}{l}\text { Ger- } \\
\text { many }\end{array}$ & Italy & $\begin{array}{l}\text { Nether- } \\
\text { lands }\end{array}$ & Spain & $\begin{array}{c}\text { Swe- } \\
\text { den }\end{array}$ & $\begin{array}{c}\text { Great } \\
\text { Britain } \\
\end{array}$ & $\begin{array}{l}\text { United } \\
\text { States }\end{array}$ \\
\hline${ }_{B, C}^{\text {Country }} \overbrace{}^{C / 8}$ & -9 & 9 & 14 & 1 & 12 & 3 & 13 & 3 & 15 & -5 & -1 & 6 & 3 \\
\hline China & 1578 & 734 & 886 & 459 & 1014 & 1323 & 1792 & 1550 & 87 & 1492 & 1169 & 702 & 1432 \\
\hline $\begin{array}{c}\text { Czech } \\
\text { Republic }\end{array}$ & 341 & 691 & 1268 & 1265 & 1189 & 732 & 421 & 229 & 561 & 8211 & 3433 & 805 & 1254 \\
\hline Hungary & 20 & 264 & 6207 & 3667 & 5359 & 2488 & 739 & 818 & 578 & 8762 & 2404 & 2445 & 2255 \\
\hline Japan & -9 & -61 & -83 & -90 & -86 & -75 & -45 & -63 & -66 & -53 & -63 & -78 & -78 \\
\hline Korea & -4 & -6 & -58 & -67 & 56 & 0 & -43 & -2 & -18 & 93 & 277 & -1 & -63 \\
\hline Poland & 425 & 1 & 221 & 926 & 71 & 810 & 369 & 49 & 40 & 37 & 361 & 19 & 85 \\
\hline Slovakia & 432 & 334 & 63 & 15419 & 4689 & 31069 & 1250 & 1227 & 4034 & 36760 & 31921 & 45203 & 34 \\
\hline Turkey & 1643 & 913 & 2428 & -27 & 352 & 982 & 39 & 194 & -37 & 2023 & 515 & 469 & 840 \\
\hline Taiwan & -51 & -52 & -63 & -77 & -48 & -67 & -30 & 7 & -86 & 5 & -12 & -61 & -56 \\
\hline
\end{tabular}

\section{B. Empirical estimates}

Our econometric analysis wants to verify whether exchange rate variations have an effect on the allocation of tasks in the global production network consistent with that predicted by the theoretical model. To verify this preposition we used the following linear model, to test the effects of exchange rate variations on the share of fragments produced in each country of the global production network.

$$
\vartheta_{j, S, t}=\beta_{1}+\beta_{2} a_{j t}+\beta_{3} N E E R_{A, t}+\beta_{4} N E E R_{B, t}+\beta_{5} N E E R_{C, t}+\varepsilon_{i t} \quad j=A, B, C
$$

where $N E E R_{j t}$ is the nominal effective exchange rate of country $j$ at time $t, a_{j t}$ is the labor productivity of country $j$ at time $t$, and subscript $S$ identifies the sector ${ }^{6}, \varepsilon_{i t}$ is a well-behaved error.

We tested the model using two samples: the first one is the complete one, with 13 countries and 12 industries. The second sample used restricts the range of industries, using Japan as country $B$. Results of the model are shown in Tables 7, 8, 9, 10, 11 and 12.

\footnotetext{
${ }^{6}$ Yearly data. NEERs data retrieved from the Bank for International Settlements; labor productivity (output per hour) data from Us Bureau of Labor Statistics and OECD Stan database.
} 
Table 7. Panel regression for the share of fragments values produced by Country $A$

\begin{tabular}{lcccccc}
\hline \multicolumn{7}{c}{$\vartheta$ Country $A$} \\
\hline NEER & {$[$ Japan $]$} & {$[$ Japan $]$} & {$[$ Slovakia $]$} & {$[$ Slovakia $]$} & {$[$ Czech Rep $]$} & {$[$ Czech Rep $]$} \\
\hline Country $A$ & -.10 & -.10 & -.10 & -.10 & -.10 & -.10 \\
\hline NEER & .04 & .03 & .14 & .12 & .16 & .16 \\
China & $(.03)^{* * *}$ & $(.03)^{* * *}$ & $(.03)^{* * *}$ & $(.03)^{* * *}$ & $(.03)^{* * *}$ & $(.03)^{* * *}$ \\
\hline NEER & -.10 & -.12 & -.11 & -.12 & -.18 & -.19 \\
Country $B$ & $(.04)^{* * *}$ & $(.04)^{* * *}$ & $(.02)^{* * *}$ & $(.03)^{* * *}$ & $(.02)^{* * *}$ & $(.02)^{* * * *}$ \\
\hline PROD & & .01 & & .01 & & .01 \\
Country $A$ & & $(.01)$ & & $(.01)$ & & $(.02)$ \\
\hline Obs & 2339 & 2339 & 2339 & 2339 & 2339 & 2339 \\
R & .70 & .71 & .71 & .71 & .71 & .71 \\
\hline
\end{tabular}

(Note) Standard errors in parentheses. * significant at 10\% level, ** 5\%,*** $1 \%$.

Values of $\vartheta$ were multiplied by 100 .

Table 8. Panel regression for the share of fragments values produced by Country $A$

\begin{tabular}{lcccccc}
\hline \multicolumn{7}{c}{$\vartheta$ C_Country $A$} \\
\hline NEER & {$[17$ to 18$]$} & {$[24]$} & {$[26]$} & {$[27$ to 28$]$} & {$[30$ to 33] } & [34 to 35] \\
Country $A$ & .06 & -.09 & -.04 & -.15 & -.10 & -.17 \\
\hline NEER & $.03)^{* *}$ & $(.04)^{* *}$ & $(.01)^{* * *}$ & $(.06)^{* *}$ & $(.05)^{* *}$ & $(.03)^{* * *}$ \\
China & .10 & -.05 & -.003 & .03 & .19 & -.09 \\
\hline NEER & $.05)^{* *}$ & $(.05)$ & $(.01)$ & $(.07)$ & $(.06)^{* * *}$ & $(.06)$ \\
Japan & -.12 & -.26 & -.05 & -.24 & -.03 & -.23 \\
\hline PROD & $(.06)^{* *}$ & $(.05)^{* * *}$ & $(.02)^{* * *}$ & $(.08)^{* * *}$ & $(.08)$ & $(.07)^{* * *}$ \\
Country $A$ & .06 & .05 & -.02 & .02 & -.09 & .06 \\
\hline Obs & $(.03)^{* *}$ & $(.04)^{* *}$ & $(.01)^{* * *}$ & $(.03)$ & $(.03)^{* *}$ & $(.03)^{*}$ \\
\hline R & 195 & 195 & 195 & 195 & 195 & 195 \\
\hline
\end{tabular}

(Note) Standard errors in parentheses. * significant at 10\% level, ** 5\%, *** $1 \%$.

Values of $\vartheta$ were multiplied by 100 . 
Table 9. Panel regression for the share of fragments values produced by Country $B$

\begin{tabular}{|c|c|c|c|c|c|c|}
\hline & & & $\vartheta \_\mathrm{Col}$ & intry $B$ & & \\
\hline & [Japan] & [ Japan] & [ Czech Rep.] & [ Czech Rep] & [Slovakia] & [ Slovakia] \\
\hline NEER & .0002 & .001 & .008 & .006 & .0002 & -.000 \\
\hline Country $A$ & $(.001)$ & $(.001)$ & $(.005)$ & $(.003)^{* *}$ & (.0004) & $(.000)$ \\
\hline NEER & -.003 & -.003 & -.008 & -.01 & -.0008 & -.001 \\
\hline China & $(.001)^{* * *}$ & $(.001)^{* * *}$ & (.008) & $(.004) * * *$ & $(.0004)^{* *}$ & $(.0004) * * *$ \\
\hline NEER & -.003 & -.24 & .02 & .009 & .001 & .001 \\
\hline Country $B$ & $(.002)$ & $(.08)^{* * *}$ & $(.014)$ & $(.008)$ & (.0004) & $(.0004)^{*}$ \\
\hline PROD & & -.003 & & -.004 & & -.001 \\
\hline Country $A$ & & $(.001)^{* * *}$ & & $(.002)^{*}$ & & $(.0003) * * *$ \\
\hline PROD & & .0002 & & & & \\
\hline China & & $(.0004)$ & & & & \\
\hline PROD & & .001 & -.004 & .002 & .001 & .002 \\
\hline Country B & & $(.001)$ & $(.007)$ & $(.004)$ & $(.0002) * * *$ & $(.0003) * * *$ \\
\hline Obs & 2339 & 2339 & 2339 & 2339 & 2339 & 2339 \\
\hline $\mathrm{R}^{2}$ & .55 & .56 & .61 & .61 & .49 & .49 \\
\hline
\end{tabular}

(Note) Standard errors in parentheses. * significant at 10\% level, ** 5\%,*** $1 \%$.

Values of $\vartheta$ were multiplied by 100 .

Table 10. Panel regression for the share of fragments values produced by Country $B$

[ Industry in brackets ]

(1995 2009)

\begin{tabular}{lccccccccc}
\hline \multicolumn{10}{c}{$\vartheta_{-}$Japan } \\
\hline & {$[17$ to 18$]$} & {$[24]$} & {$[24]$} & {$[26]$} & {$[27$ to 28] } & [30 to 33] & [30 to 33] & [34 to 35] \\
\hline NEER & -.004 & .002 & .002 & .005 & -.005 & -.006 & -.014 & .01 \\
Country $A$ & $(.001)^{* * *}$ & $(.001)^{*}$ & $(.001)^{*}$ & $(.004)$ & $(.002)^{* *}$ & $(.005)$ & $(.005)^{* * *}$ & $(.004)^{* *}$ \\
\hline NEER & -.004 & -.003 & -.002 & -.001 & .01 & -.02 & -.02 & -.002 \\
China & $(.001)^{* * *}$ & $(.006)^{* * *}$ & $(.006)^{* * *}$ & $(.0005)^{* *}$ & $(.05)^{* * *}$ & $(.007)^{* * *}$ & $(.003)^{* * *}$ & $(.006)$ \\
\hline NEER & -.003 & -.24 & -.0002 & -.00 & -.005 & -.005 & -.004 & .003 \\
Country $B$ & $(.001)^{* * *}$ & $(.08)^{* * *}$ & $(.0006)$ & $(.001)$ & $(.002)^{* *}$ & $(.006)$ & $(.006)$ & $(.005)$ \\
\hline PROD & & & -.001 & -.001 & & & -.02 & -.001 \\
Country $A$ & & & $(.0005)^{* * *}$ & $(.000)^{* * *}$ & & & $(.003)^{* * *}$ & $(.003)$ \\
\hline PROD & -.002 & -.002 & -.0001 & .007 & -.004 & -.01 & .01 & .001 \\
Country $B$ & $(.00)^{* * *}$ & $(.00)^{* * *}$ & $(.0001)$ & $(.0003)^{*}$ & $(.001)^{* * *}$ & $(.004)^{* *}$ & $(.005)^{* * *}$ & $(.004)$ \\
\hline Obs & 195 & 195 & 195 & 195 & 195 & 195 & 195 & 195 \\
$\mathrm{R}^{2}$ & .67 & .94 & .94 & .85 & .78 & .82 & .86 & .87 \\
\hline
\end{tabular}

(Note) Standard errors in parentheses. * significant at 10\% level, ** 5\%, *** $1 \%$.

Values of $\vartheta$ were multiplied by 100 . 
Table 11. Panel regression for the share of fragments values produced by Country $C$ (China)

\begin{tabular}{lccccc}
\hline \multicolumn{5}{c}{$\vartheta$ Country C } \\
\hline NEER & {$[$ Japan $]$} & {$[$ Japan $]$} & {$[$ Korea $]$} & {$[$ Czech Rep $]$} & {$[$ Slovakia $]$} \\
Country $A$ & .009 & .009 & .009 & .009 & .009 \\
\hline NEER & $(.004)^{* *}$ & $(.005)^{*}$ & $(.006)^{*}$ & $(.004)^{* *}$ & $(.004)^{* *}$ \\
China & .002 & .001 & -.014 & -.017 & .001 \\
\hline NEER & $. .006)$ & $(.005)$ & $(.005)$ & $(.006)^{* * *}$ & $(.006)$ \\
Country $B$ & .005 & .001 & -.005 & -.007 & .007 \\
\hline PROD & $(.005)$ & $(.005)$ & $(.003)^{*}$ & $(.01)$ & $(.01)$ \\
China & .008 & .009 & .009 & .003 & .009 \\
\hline PROD & $(.001)^{* * *}$ & $(.002)^{* * *}$ & $(.001)^{* * *}$ & $(.004)$ & $(.006)$ \\
Country $B$ & & -.005 & & .017 & -.006 \\
\hline Obs & & $(.007)$ & & $(.008)^{* *}$ & $(.01)$ \\
$\mathrm{R}^{2}$ & 2339 & 2339 & 2339 & 2339 & 2339 \\
\hline
\end{tabular}

(Note) Standard errors in parentheses. * significant at 10\% level, ** 5\%,*** $1 \%$.

Values of $\vartheta$ were multiplied by 100 .

Table 12. Panel regression for the share of fragments values produced by Country $C$ (China)

[ Industry in brackets ]

(1995 2009)

\begin{tabular}{lccccccccc}
\hline \multicolumn{10}{c}{$\vartheta \vartheta_{-}$China } \\
\hline & {$[17]$} & {$[24]$} & {$[24]$} & {$[26]$} & {$[27]$} & {$[30]$} & {$[30]$} & {$[34]$} & {$[34$ bis $]$} \\
\hline NEER & .09 & -.001 & -.0003 & .002 & -.001 & -.01 & -.007 & .005 & .003 \\
Country $A$ & $(.02)^{* * *}$ & $(.002)$ & $(.003)$ & $(.001)^{*}$ & $(.003)$ & $(.02)$ & $(.02)$ & $(.003)$ & $(.002)$ \\
\hline NEER & -.01 & .004 & .003 & -.000 & -.000 & -.01 & -.01 & -.000 & -.004 \\
China & $(.01)$ & $(.001)^{* *}$ & $(.0015)^{* *}$ & $(.000)$ & $(.003)$ & $(.01)$ & $(.02)$ & $(.001)$ & $(.003)$ \\
\hline NEER & -.002 & -.002 & -.003 & -.000 & -.006 & -.007 & -.014 & .002 & -.003 \\
Country $B$ & $(.02)$ & $(.002)$ & $(.001)^{*}$ & $(.000)$ & $(.003)^{* *}$ & $(.015)$ & $(.01)^{*}$ & $(.002)$ & $(.001)^{*}$ \\
\hline PROD & .03 & .006 & .006 & .002 & .006 & .04 & .04 & .004 & .003 \\
China & $(.003)^{* * *}$ & $(.001)^{* * *}$ & $(.001)^{* * *}$ & $(.0003)^{* * *}$ & $(.001)^{* * *}$ & $(.003)^{* * *}$ & $(.003)^{* * *}$ & $(.001)^{* * *}$ & $(.002)^{* * *}$ \\
\hline PROD & & & -.004 & -.002 & & & .04 & -.004 & \\
Country $B$ & & & $(.003)$ & $(.001)^{* *}$ & & & $(.03)$ & $(.003)$ & \\
\hline Obs & 195 & 195 & 195 & 195 & 195 & 195 & 195 & 195 & 195 \\
$\mathrm{R}^{2}$ & .71 & .75 & .75 & .69 & .71 & .71 & .72 & .87 & .67 \\
\hline
\end{tabular}

(Note) Standard errors in parentheses. * significant at 10\% level, ** 5\%, *** $1 \%$.

Values of $\vartheta$ were multiplied by 100 . Country $B$ is always Japan, but 34 bis, in which Korea is the country $B$. 
Empirical estimation verified the hypothesis that a devaluation of the middle country's currency, reduces the share of value added in the high-productivity country, because of the similarity of comparative advantages. Table 7 summarizes the results using the complete samples. In each specification of the model a devaluation of the medium country's currency reduces the share of fragments produced in country $A$. Results are significantly different from zero, and they are robust to changes in the country $B$ of the model. The devaluation of the renminbi does not reduce the share of fragments produced in the high-productivity countries, instead it seems to increase them.

When we restrict the sample to selected industries, results still verifies the hypothesis of the model (Table 14). In fact, when the Japanese currency is devalued, high-productivity countries decrease their share of fragments. In the complete sample it seemed that a devaluation of the renminbi would increase the share of intermediate goods produced in the high-productivity countries, But the results here are less odd: the effect of the renminbi is usually not significant.

Results obtained applying the model to the share of intermediate goods produced in country $B$ verify the hypothesis of the model. Taking the whole sample, it is verified that a devaluation of the country $C$ will decrease the share of fragments produced in the medium-productivity country. Results are significantly different from zero and are robust to changes in the country $B$. Results concerning the exchange rate of the high-productivity country are less robust: in the whole sample, the effect of the exchange rate of the high-productivity country is not significant, but we found that increases in the labor productivity of country $A$ will transfer fragments from the medium-productivity country to the high-productivity one. When we restrict the sample to specific industry, results are more robust. The devaluation of the renminbi would decrease the share of fragments produced in Japan, as well as a devaluation of the currency of highproductivity countries. When the latter is not verified, we added labor productivity of country $A$, verifying that its effect is negative and significantly different from zero.

Considering China, a low-productivity country in our analysis, results are less robust when we use the complete sample. In fact, only in the case of Korea, we found results consistent with the theoretical model. The devaluation of the Korean currency would decrease the share of fragments produced in China, while the effect of the currency of the high-productivity country is positive. Nevertheless, at the industry level, results buttressed the theory. In fact, the effect of the exchange rate of country $A$ is ambiguous, sometimes positive, sometimes negative, but never in contradiction with the model. In most industries a devaluation of the Japanese currency would decrease the share of fragments produced in China, and when the exchange rate is not enough to have the consistent result, the Japanese labor productivity will. In the motor vehicle industry, it appears that Korea has a more similar comparative advantage to that of China than the Japanese case.

Given these results, the two samples of the model buttressed the hypothesis that exchange rate variations affect the range of fragments produced in countries within the global production networks, only if they have a similar comparative advantage. 


\section{Conclusions}

Our theoretical model suggests that exchange rate variations to the same global production network will transfer fragments among them only if the set of fragments each of them specializes in are close in the continuum. Empirical evidence presented in this paper does not allow for a rejection of the theoretical hypothesis. The range of fragments produced in a country is changed only by the exchange rates between that country's currency and those of the countries that exhibit the closer comparative advantage. In particular, high-productivity countries can vary their specialization only by managing the exchange rate with the currency of mediumproductivity countries. A revaluation of the currency of low-productivity country would not modify the production structure of high-productivity country, while it may increase the share of fragments produced in the medium-productivity one.

The implications are momentous. Take a look at the debate about the 'appropriateness' of the US dollar - Chinese renminbi exchange rate. To increase employment in the US, many observers and economists, notably Paul Krugman (2010), invoked a revaluation of a renminbi. An increased dollar price of the fragments produced in China would, according to current theories, bring the fragments back to the US (Marsh, 2011; The Economist, 2011). Re-shoring would, in theory, restore manufacturing employment to levels recorded before the emergence of global production networks. However, on the basis of our model, a revaluation of the renminbi would have no effects on the US production of intermediates: rather, revaluating the renminbi would reduce Chinese competitiveness vis-à-vis medium-productivity countries, like Taiwan. In addition to that, the emergence of new countries would suggest a scenario where history repeats itself (Leunig, 2011). Just as high per capita income countries outsourced their production processes in medium- and low-productivity countries, there will be a period in which currently low-productivity countries will start the process all over again. China will move up along the continuum of fragments, transferring the simplest activities to the new members of the global production network, like Vietnam or Bangladesh (Feldstein, 2011). As always, the extent of the market is the only limit to the international division of labor (Smith, 1776).

Received 4 December 2012, Revised 5 April 2013, Accepted 1 May 2013

\section{References}

Amighini, A. (2005). China in the international fragmentation of production: Evidence from the ICT industry. The European Journal of Comparative Economics, 2(2), 203-219.

Ando, M. (2006). Fragmentation and vertical intra-industry trade in East Asia. The North American Journal of Economics and Finance, 17(3), 257-281. 
Antràs, P., Garicano, L., \& Rossi-Hansberg, E. (2005). Offshoring in a knowledge economy. Quarterly Journal of Economics.

Athukorala, P.-chandra. (2005). Product Fragmentation and Trade Patterns in East Asia. Asian Economic Papers, 4(3), 1-27. MIT Press.

Autor, H. D., Levy, F., \& Murnane, R. (2003). The skill content of recent technological change: An empirical exploration. The Quarterly Journal of, (November), 1279-1333.

Baldone, S., Sdogati, F., \& Tajoli, L. (2007). On some effects of international fragmentation of production on comparative advantages, trade flows and the income of countries. The World Economy, 30(11), 1726-1769.

Baldone, S., Sdogati, F., \& Tajoli, L. (2001). Patterns and determinants of international fragmentation of production: Evidence from outward processing trade between the EU and Central Eastern European countries. Weltwirtschaftliches Archiv, 137(1), 80-104.

Baldwin, R. (2009). Integration of the North American economy and new-paradigm globalization. Working Paper Series 049 - Policy Research Initiative - Government of Canada, (September). Policy Research Initiative (PRI).

Baldwin, R., \& Venables, A. (2010). Relocating the Value Chain: Offshoring and Agglomeration in the Global Economy (pp. 0-34).

Bird, G., \& Rajan, R. S. (2004). Does devaluation lead to economic recovery or contraction? Theory and policy with reference to Thailand. Journal of International Development, 16(2), 141-156.

Buffie, E.F.(1986). Devaluation and Imported Inputs: The Large Economy Case. International Economic Review, 27(1), 123-140. JSTOR.

Chang, W.W., \& Mayer, W. (1973). Intermediate goods in a general equilibrium trade model. International Economic Review, 14(2), 447-459. JSTOR.

Cheung, Y.W., Chinn, M.D., \& Fujii, E. (2007). The overvaluation of renminbi undervaluation. Journal of International Money and Finance, 26(5), 762-785. Elsevier.

Cline, W.R., \& Williamson, J. (2008). Estimates of the equilibrium exchange rate of the renminbi: is there a consensus and, if not, why not? Exchange Organizational Behavior Teaching Journal, (2006), 131-54.

Costinot, A., Vogel, J., \& Wang, S. (2011). An Elementary Theory of Global Supply Chains. NBER.

Das, S. P. (1980). Traded Intermediate Products, and the Theory of Devaluation. International Economic Review, 21(2), 317-330. JSTOR.

Deardorff, A.V. (1979). Weak links in the chain of comparative advantage. Journal of International Economics, 9(2), 197-209. Elsevier.

Deardorff, A.V. (2001). Fragmentation in simple trade models. The North American Journal of Economics and Finance, vol. 12(2), pages 121-137, July. Elsevier

Dixit, A.K., \& Grossman, G.M. (1982). Trade and protection with multistage production. The Review of Economic Studies, 49(4), 583. Oxford University Press.

Dornbusch, R., Fischer, S., \& Samuelson, P. A. (1977). Comparative advantage, trade, and payments in a Ricardian model with a continuum of goods. The American Economic Review, 67(5), 823-839. JSTOR.

Durkin Jr, J. T., \& Krygier, M. (2000). Differences in GDP per capita and the share of intraindustry trade: The role of vertically differentiated trade. Review of International Economics, 8(4), 760-774. 
Escaith, H., \& Gonguet, F. (2009). International Trade and Real Transmission Channels of Financial Shocks in Globalized Production Networks. World Trade Organization Staff Working Paper, (May), 1-32.

Ethier, W.J. (1979). Internationally decreasing costs and world trade. Journal of International Economics, 9(1), 1-24. Elsevier.

Ethier, W.J. (1982). National and international returns to scale in the modern theory of international trade. The American Economic Review, 72(3), 389-405. JSTOR.

Ethier, W.J. (2005). Globalization, globalisation: trade, technology, and wages. International Review of Economics \&amp; Finance.

Fair, R. (2010). Estimated macroeconomic effects of a Chinese yuan appreciation. Business Economics.

Feenstra, R.C., \& Jensen, J. B. (2009). Evaluating Estimates of Materials Offshoring from US Manufacturing. Conference on Measurement Issues Arising from the Growth of Globalization, Washington, DC.

Feenstra, Robert C, \& Hanson, G. H. (2008). Globalization, Outsourcing, and Wage Inequality. Review Literature And Arts Of The Americas, 86(2).

Feenstra, Robert C, Hanson, G. H., \& Swenson, D. L. (1999). Offshore Assembly from the United States : Production Characteristics of the 9802 Program by. Program, (June).

Feldstein M. (2011). China’s New Currency Policy. Project Syndicate.

Findlay, R., \& Rodriguez, C. A. (1977). Intermediate imports and macroeconomic policy under flexible exchange rates. Canadian Journal of Economics, 10(2), 208-217. JSTOR.

Foster, N., Stehrer, R., \& de Vries, G. (2011). Patterns of net trade in value added and factors, (225).

Fukao, K., Ishido, H., \& Ito, K. (2003). Vertical intra-industry trade and foreign direct investment in East Asia. Journal of the Japanese and International Economies, 17(4), 468-506. Elsevier.

Gabrisch, H., \& Segnana, M. L. (2008). Vertical and horizontal patterns of intra-industry trade between EU and candidate countries. Dynamic capabilities between firm organization and local systems of production, 37(7), 324. Taylor \& Francis.

Gamberoni, E., Lanz, R., \& Piermartini, R. (2010). Timeliness and Contract Enforceability in Intermediate Goods Trade. WTO.

Grossman, G.M.\& Rossi-Hansberg, E. (2006). The rise of offshoring: it's not wine for cloth anymore. The New Economic Geography:

Grossman, G.M.\& Rossi-Hansberg, Esteban(2011). Task trade between similar countries. Policy Research Working Paper Series 5819, The World Bank.

Grossman, G.M.\&Rossi-Hansberg, E. (2008). Trading Tasks: A Simple Theory of Offshoring. American Economic Review, 98(5), 1978-1997.

Guisinger, S.E. (1969). Negative Value Added and the Theory of Effective Protection. The Quarterly Journal of Economics, 83(3), 415. Oxford University Press.

Gylfason, T.\& Schmid, M. (1983). Does Devaluation Cause Stagflation? The Canadian Journal of Economics, $16(4), 641$.

Hanson, J. A. (1983). Contractionary devaluation, substitution in production and consumption, and the role of the labor market. Journal of International Economics, 14(1-2), 179-189. Elsevier. 
Helg, R., \& Tajoli, L. (2005). Patterns of international fragmentation of production and the relative demand for labor. The North American Journal of Economics and Finance, 16(2), 233-254.

Hijzen, A., Görg, H. \& Hine, R. C. (2005). International Outsourcing and the Skill Structure of Labour Demand in the United Kingdom. The Economic Journal, 115(506), 860-878.

Hummels, D.L., Ishii, J. \& Yi, K.M. (1999). The Nature and Growth of Vertical Specialization in World Trade. SSRN Electronic Journal.

Johnson, R.C. \& Noguera, G. (2011). Accounting for intermediates: Production sharing and trade in value added. World, 1-40.

Jones, R.W. \& Sanyal, K.K. (1982). The theory of trade in middle products. The American Economic Review, 72(1), 16-31. JSTOR.

Jones, R.W. \& Kierzkowski, H. (1990). The Role of Services in Production and International Trade: A Theoretical Framework," in Ronald W. Jones and Anne O. Krueger, eds., The Political Economy of International Trade: Essays in Honor of Robert E. Baldwin, Cambridge, MA: Blackwell, pp. 31-48

Jones, R.W., Kierzkowski, H.\& Lurong, C. (2005). What does evidence tell us about fragmentation and outsourcing? International Review of Economics \& Finance, 14(3), 305-316.

Kohler, W. (2001). A specific-factors view on outsourcing. The North American Journal of Economics and Finance, 12(1), 31-53. Elsevier.

Krugman, P. (2010). Taking on China. New York Times, 14, 2010-2011.

Lamy, P. (2011). "Made in China" tells us little about global trade. Financial Times, WTO - Made in the World, 24.

Leamer, E.E.\& Storper, M. (2001). The economic geography of the internet age. Journal of International Business Studies (pp. 1-37).

Leunig, B.T. (2011). “Reshoring” jobs from China won ’t happen. Financial Times, 21-22.

Marjit, S. (1987). Trade in intermediates and the colonial pattern of trade. Economica, 54(214), 173-184. JSTOR.

Marquez, J.\& Schindler, J. (2007). Exchange-rate Effects on China' s Trade *. Review Literature And Arts Of The Americas, 15(5), 837-853.

Marsh, B.P. (2011). China labour costs push jobs back to US. Financial Times, 4-5.

McKinnon, R.I. (1966). Intermediate products and differential tariffs: A generalization of Lerner's symmetry theorem. The Quarterly Journal of Economics, 80(4), 584. Oxford University Press.

McKinnon, R.I. \& Schnabl, G. (2004). The East Asian Dollar Standard, Fear of Floating, and Original Sin. Review of Development Economics, 8(3), 331-360.

Melecky, M. (2008). A Structural Investigation of Third-Currency Shocks to Bilateral Exchange Rates. International Finance, 11(1), 19-48. Wiley Online Library.

Melvin, J. (1969). Intermediate Goods in Production Theory: The Differentiable Case. The Review of Economic Studies, 36(1), 124-131.

Ng, F., \& Yeats, A. (2001). Production sharing in East Asia: who does what for whom, and why? Global production and trade in East Asia, 63-109. Boston: Kluwer Academic Publishers. 
Ng, E.C.Y.(2010).Production fragmentation and business-cycle comovement. Journal of International Economics, vol. 82(1), pages 1-14, September, Elsevier.

Nordås, H.K. (2006). International production sharing: a case for a coherent policy framework. Time. World Trade Organization.

Rowthorn, B.\& Ramaswamy, R. (1997). Deindustrialization: causes and implications. International Monetary Fund.

Saeger, S. (1997). Globalization and Deindustrialization: Myth and Reality in the OECD. Review of World Economics.

Sanyal, K.K. (1983). Vertical Specialization in a Ricardian Model with a Continuum of Stages of Production. Economica, 50(197), 71.

Sarkar, A. (1985). A model of trade in intermediate goods. Journal of International Economics, 19(1-2), 85-98. Elsevier.

The Economist(2011). Moving back to America. pp. 1-2.

Thorbecke, W. \& Smith, G. (2010). How Would an Appreciation of the Renminbi and Other East Asian Currencies Affect China's Exports? Review of International Economics, 18(1), 95-108. Wiley Online Library.

Thorbecke, W.\& Zhang, H. (2009). The Effect of Exchange Rate Changes on China's Labor-Intensive Manufacturing Exports. Pacific Economic Review, 14(3), 398-409.

Türkcan, K.\& Ates, A. (2011). Vertical Intra-industry Trade and Fragmentation: An Empirical Examination of the US Auto-parts Industry. The World Economy, 34(1), 154-172.

Vanek, J. (1963). Variable factor proportions and interindustry flows in the theory of international trade. The Quarterly Journal of Economics, 77(1), 129. Oxford University Press.

WTO; IDE-JETRO. (2011). Trade patterns and global value chains in East Asia: from trade in goods to trade in tasks.

Warne, R.D. (1971). Intermediate goods in international trade with variable proportions and two primary inputs. The Quarterly Journal of Economics, 85(2), 225. Oxford University Press.

Westerlund, J. \& Edgerton, D.L. (2007). New Improved tests for cointegration with structural breaks. Journal of Time Series Analysis, 28(2), 188-224. Wiley Online Library.

Wu, Y. (2010). Exchange Rates and Prices under Processing Trade: A Macroeconomic Analysis. Atlantic Economic Journal, 38(3), 345-357. Zeddies, G. (2007). Determinants of international fragmentation of production in European Union. Empirica, (0). 